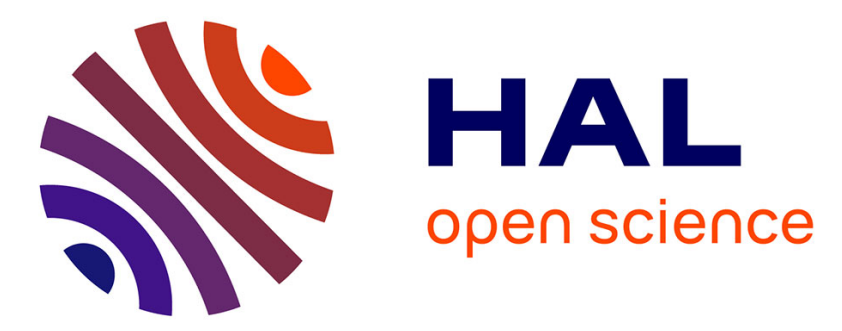

\title{
French lay people's views regarding the acceptability of involuntary hospitalization of patients suffering from psychiatric illness
}

Myriam Guedj, Paul C Sorum, Etienne Mullet

\section{- To cite this version:}

Myriam Guedj, Paul C Sorum, Etienne Mullet. French lay people's views regarding the acceptability of involuntary hospitalization of patients suffering from psychiatric illness. International Journal of Law and Psychiatry, 2012, 35 (1), pp.50-56. 10.1016/j.ijlp.2011.11.010 . hal-01953098

\section{HAL Id: hal-01953098 \\ https://hal-univ-tlse2.archives-ouvertes.fr/hal-01953098}

Submitted on 12 Dec 2018

HAL is a multi-disciplinary open access archive for the deposit and dissemination of scientific research documents, whether they are published or not. The documents may come from teaching and research institutions in France or abroad, or from public or private research centers.
L'archive ouverte pluridisciplinaire HAL, est destinée au dépôt et à la diffusion de documents scientifiques de niveau recherche, publiés ou non, émanant des établissements d'enseignement et de recherche français ou étrangers, des laboratoires publics ou privés. 


\section{AUTHOR QUERY FORM}

\begin{tabular}{|l|l|l|}
\hline $\begin{array}{l}\text { J. } \\
\text { ELSEVIER }\end{array}$ & Journal: IJLP & $\begin{array}{l}\text { Please e-mail or fax your responses and any corrections to: } \\
\text { E-mail: corrections.esil@elsevier.spitech.com }\end{array}$ \\
Article Number: 846 & Fax: +1 6196996721 \\
\hline
\end{tabular}

Dear Author,

Please check your proof carefully and mark all corrections at the appropriate place in the proof (e.g., by using on-screen annotation in the PDF file) or compile them in a separate list. Note: if you opt to annotate the file with software other than Adobe Reader then please also highlight the appropriate place in the PDF file. To ensure fast publication of your paper please return your corrections within 48 hours.

For correction or revision of any artwork, please consult http://www.elsevier.com/artworkinstructions.

Any queries or remarks that have arisen during the processing of your manuscript are listed below and highlighted by flags in the proof. Click on the 'Q' link to go to the location in the proof.

\begin{tabular}{|l|l|}
\hline Location in article & \multicolumn{1}{c|}{$\begin{array}{c}\text { Query / Remark: click on the Q link to go } \\
\text { Please insert your reply or correction at the corresponding line in the proof }\end{array}$} \\
\hline Q1 & Please confirm that given names and surnames have been identified correctly. \\
\hline Q2 & $\begin{array}{l}\text { The citation "Steinert, 2009" has been changed to match the author name/date in the reference list. } \\
\text { Please check here and in subsequent occurrences, and correct if necessary. }\end{array}$ \\
\hline Q4 & $\begin{array}{l}\text { The citation "Dawson \& Kämpft, 2006" has been changed to match the author name/date in the } \\
\text { reference list. Please check here and in subsequent occurrences, and correct if necessary. }\end{array}$ \\
\hline Q5 & $\begin{array}{l}\text { Citation "Lidz, Mulvey \& Gardner, 1993" has not been found in the reference list. Please supply } \\
\text { full details for this reference. }\end{array}$ \\
\hline Q6 & $\begin{array}{l}\text { The citation "Luchins, Cooper, and Rasinski (2004)" has been changed to match the author name/ } \\
\text { date in the reference list. Please check here and in subsequent occurrences, and correct if necessary. }\end{array}$ \\
\hline Q7 & $\begin{array}{l}\text { The citation "Luchins, Hanrahan, and Heyrman (2006)" has been changed to match the author } \\
\text { name/date in the reference list. Please check here and in subsequent occurrences, and correct if } \\
\text { necessary. }\end{array}$ \\
\hline Q8 & $\begin{array}{l}\text { Citation "Lepping, Steinert \& Röttgers, 2004" has not been found in the reference list. Please } \\
\text { supply full details for this reference. }\end{array}$ \\
\hline Q9 & $\begin{array}{l}\text { Citation "Esterle, Munoz Sastre, \& Mullet, 2008" has not been found in the reference list. Please } \\
\text { supply full details for this reference. }\end{array}$ \\
\hline $\begin{array}{l}\text { Uncited references: This section comprises references that occur in the reference list but not in the } \\
\text { body of the text. Please position each reference in the text or, alternatively, delete it. Any reference } \\
\text { not dealt with will be retained in this section. Thank you. }\end{array}$ \\
\begin{tabular}{l} 
Please provide an update for reference Bonnie and Monahan, in press. \\
\hline
\end{tabular}
\end{tabular}

Thank you for your assistance. 


\title{
French lay people's views regarding the acceptability of involuntary hospitalization of patients suffering from psychiatric illness
}

\author{
Q13 Myriam Guedj a , Paul C. Sorum ${ }^{\text {b,* }}$, Etienne Mullet ${ }^{c}$ \\ a Department of Psychology, Mirail University, 5, Allées Antonio-Machado, F-31058 Toulouse Cedex 9, France \\ ${ }^{\mathrm{b}}$ Departments of Internal Medicine and Pediatrics, Albany Medical College, Albany, NY 12308, USA \\ ${ }^{c}$ Institute of Advanced Studies, Paris, France
}

\section{A R T I C L E I N F O}

Available online $\mathrm{xxxx}$

\section{Keywords:}

Involuntary hospitalization

Mental illness

Threat to others

Beneficence

Autonomy

France

\begin{abstract}
A B S T R A C T
Purpose: To understand how lay people and health professionals in France judge the acceptability of hospi= 22 talizing a psychiatric patient against his will.

Methods: 123 lay people, 20 nurses, 5 psychologists, and 6 physicians judged the acceptability of involuntary hospitalization in each of 36 scenarios consisting of all combination of 4 factors: patient's adherence to 25 treatment (agrees to take his medications or not); risk of suicide (none, immediate, multiple past attempts); risk 26 of harming others (none, immediate, history of violence against others); attitude of patient's family (favorable to 27 involuntary hospitalization or not). The judgment data were subjected to cluster analysis and subsequently to 28 analysis of variance.

Results: 4 clusters were identified and labeled according to the factors that affected judgments: Never Favorable 30 ( 7 participants, with mean acceptability judgment of 1.30 on a scale of $0-10$ ); Threat to Others (35, with mean 31 judgment of 8.68 when risk high, 2.94 when risk low), Threat to Others or Self and Adherence (88, with mean 32 judgment of 6.89), and Always Favorable (24, with mean judgment of 8.41).

Conclusions: $95 \%$ of participants agreed that involuntary hospitalization is acceptable under certain conditions, 34 especially - in accordance with French law - when the patient presents a risk to others.
\end{abstract}

(c) 2011 Published by Elsevier Ltd. 36

\section{Introduction}

The involuntary hospitalization of psychiatric patients has a long tradition in Western countries. It is legal under circumstances that vary from one country to another (Dawson \& Kämpf, 2006; Habermeyer, Rachvoll, Felthous, Bukhanowsky, \& Gleyzer, 2007; Kallert, Rymaszewska, \& Torres-Gonzalez, 2007; Steinert \& Lepping, 2009), although the basic requirement is, of course, that the patient suffers from a mental disorder.

Article 5 of the European Convention on Human Rights provides that "Everyone has the right to liberty and security of person. No one shall be deprived of his liberty save in the following cases and in accordance with a procedure prescribed by law: ...(e) the lawful detention of persons for the prevention of the spreading of infectious diseases, of persons of unsound mind, alcoholics or drug addicts or vagrants." Article 8 reiterates, more generally, that there can be "no interference by a public authority with this right [to respect for private and family life] except such as in accordance with the law and is necessary in a democratic society in the interests of national

\footnotetext{
* Corresponding author at: Latham Med-Ped, 724 Watervliet-Shaker Road, Latham, New York 12110, USA. Tel.: +1 518262 7500; fax: +1 5182627505

E-mail addresses: guedj@univ-tlse2.fr (M. Guedj), sorump@mail.amc.edu (P.C. Sorum), etienne.mullet@wanadoo.fr (E. Mullet).
}

security, public safety or the country, for the prevention of disorder 59 or crime, for the protection of health or morals, or for the protection 60 of the rights and freedoms of others." (European Court of Human 61 Rights, 2010). The United Nation's Convention on the Rights of Per- 62 sons on Disabilities of 2006 enjoins signing states to "undertake to en- 63 sure and promote the full realization of all human rights and 64 fundamental freedoms for all persons with disabilities without dis- 65 crimination of any kind on the basis of disability" (Article 4) and, in 66 particular, to ensure that persons with disabilities "are not deprived 67 of their liberty unlawfully or arbitrarily, and that any deprivation of 68 liberty is in conformity with the law, and that the existence of a dis- 69 ability shall in no case justify a deprivation of liberty" (Article 14) 70 (United Nations, 2006). It provides strong support for limiting the in- 71 voluntary institutionalization and treatment of people with mental 72 illness and other disabilities (Lee, 2011). Meanwhile, the European 73 Court of Human Rights has repeatedly ruled that involuntary confine- 74 ment is valid only if it is accord with national law and if it complies 75 with the requirements set forth in the Court's 1979 judgment in Win- 76 terwerp $v$ the Netherlands: "it must have been reliably established, 77 through objective medical expertise, that the patient has a true men- 78 tal disorder; the mental disorder must be of a kind or degree warrant- 79 ing compulsory confinement; the validity of continued confinement 80 depends upon the persistence of such a disorder" (European Court 81 of Human Rights, 2011).

22 23 (1) 
In France, legislation in 1990 established that patients with capacity must give their consent to be admitted to a hospital (Dawson \& Kämpf, 2006; Loi no 90-527 du 27 juin, 1990). The patient's family (or another person acting in the patient's interest) can, however, obtain involuntary hospitalization under two conditions: if, as confirmed by two psychiatrists, the patient's mental illness renders him or her incapable of "consent" (and, by implication, of the capacity to make decisions) and if his or her condition requires immediate care under constant supervision in the hospital. In addition, the civil authorities can require hospitalization when, as confirmed by a psychiatrist or by public notoriety, the psychiatric patient poses an imminent threat to others' safety or, more generally, to public order. This legislation has been upheld in recent decisions of French courts of appeals concerning psychiatric patients who refused treatment (Cour d'appel d'Aix-en-Provence, 2008) and who presented a threat of violence against others (Cour d'appel de Bordeaux, 2006). France ratified in February 2010 the UN Convention on the Rights of Persons with Disabilities. Nonetheless, the recent alteration of the 1990 law (Loi $n^{\circ}$ 2011-803 du 5 juillet, 2011) did not change the law's basic principles regarding involuntary hospitalization.

Involuntary hospitalization is, however, among the most controversial and debated issues in mental health care. It has, repeatedly and increasingly, been the focus of criticisms from human rights advocates, political bodies, and patients' families (Kallert, Glöckner, \& Schützwohl, 2008). It clearly involves an ethical conflict (Alexius, Berg, \& Aberg-Wistedt, 2002; Monahan, Swartz, \& Bonnie, 2003; Putkonen \& Vollm, 2007; Wynn, Myklebust, \& Bratlid, 2007). The principle of autonomy of the patient is superseded by the principles of beneficence toward the patient and responsibility to society, i.e. to those who might be affected by the patient's actions. Autonomy is demoted on the grounds, first, that the patient lacks insight into his or her psychiatric illness and, as a result, refuses or is unable to adhere to appropriate treatment, and/or, second, that the patient is likely to harm him- or herself or others if not hospitalized and adequately treated. If autonomy were allowed to supersede public safety, violent patients would end up being handled through the system of criminal law (Szmukler \& Holloway, 1998). As observed by Monahan et al. (2003), the process of deinstitutionalizing mentally ill patients in the US has resulted in a $90 \%$ reduction in the mental hospital population, but it also has resulted in a concomitant increase in the number of inmates with serious mental troubles.

Involuntary hospitalization has also been the focus of criticisms from psychological and sociological researchers (Monahan, 1992; Taylor \& Monahan, 1996). Involuntary hospitalization is mostly decided on the basis of the anticipation of future violence to oneself or others, which is a much more difficult prediction to make than is usually appreciated by the public and by the clinicians themselves (Lidz, Mulvey \& Gardner, 1993; Monahan, 2006), even if main risk factors are better known now than 25 years before (Skeem, Miller, Mulvey, Tieman, \& Monahan, 2005); clinicians systematically over-predict violence among psychiatric patients. Valid, standardized instruments for predicting future violence are available (e.g., Monahan et al., 2006), but the extent to which these instruments are used by health professionals at the time of recommending mentally ill patients' hospitalization is limited (Monahan, 2006) or unknown (e.g., in European countries).

Psychological and sociological researchers also argue that involuntary hospitalization is not the only option that can be considered when patients do not adhere to treatment and, as a result, are liable to become violent (Monahan et al., 2003). Patients can be led to adherence in a contractual way rather than in a coercive way. They can be offered housing or money (disability benefits) in exchange for treatment adherence. They can avoid being incarcerated for the troubles for which they are responsible if they agree to be treated; that is, a court can make treatment adherence a condition for suspending their sentence. Even if in practice, the distinction between coercion and contract may be considered as artificial, this distinction 149 can be made real (Bonnie \& Monahan, in press).

\subsection{Lay people's and professionals' attitudes concerning involuntary 151} hospitalization

Pescosolido, Monahan, Link, Stueve, and Kikuzawa (1999) exam- 153 ined American lay people's opinions about the use of legal coercion 154 to force treatment of persons with mental health problems. Most 155 people considered that patients suffering from schizophrenia are 156 not very able or not able at all to make treatment decisions (74.3\%), 157 are somewhat likely or very likely to do something violent to others 158 (60.9\%) or to self (86.5\%), and should be admitted to the hospital if 159 dangerous to others (90.5\%) or to self (94.8\%). More educated people 160 were less likely to express these views than less educated people. 161

Elger and Harding (2004) compared law students' and medical 162 students' views regarding the involuntary hospitalization of suicidal 163 patients suffering from Huntington disease. There were few differ- 164 ences between the two groups: 44\% of the law students and 49\% of 165 the medical students agreed with involuntary hospitalization. Luchins, $166 \mathbf{Q 5}$ Cooper, Hanrahan, and Rasinski (2006a) examined the opinions of 167 psychiatrists regarding involuntary hospitalization and found that 168 decisions to hospitalize were positively associated with the level of pos- 169 sible harm and differed as a function of the psychiatric diagnosis. In a 170 subsequent study, Luchins, Hanrahan, and Heyrman (2006b) examined 171 Q6 the opinions of lawyers and had findings consistent with those of Elger 172 and Harding (2004): decisions to hospitalize were positively associated 173 with perceived level of risk of causing harm to others and with adher- 174 ence to treatment.

Steinert, Lepping, Baranyai, Hoffmann, and Leherr (2005) conducted 176 a cross-cultural study involving psychiatrists, other professionals, 177 and lay people from four European countries: England, Germany, 178 Hungary, and Switzerland. Participants were presented with scenarios 179 describing patients with schizophrenia and indicated whether they 180 should support involuntary hospitalization in each case. In the case 181 describing a first episode associated with social withdrawal, 74\% of 182 the participants agreed with compulsory hospitalization. In the 183 case of recurrent episodes and moderate danger to others, 87\% of 184 the participants agreed with compulsory hospitalization. Psychologists 185 and social workers were, however, significantly less in agreement 186 with that decision than psychiatrists, nurses, and lay people. Overall, 187 there were only small differences in percentages of agreement from 188 one country to the other (see also Lepping, Steinert \& Röttgers, 2004). 189 Q7

Wynn, Myklebust, and Bratlid (2006) used three scenarios to ex- 190 amine the opinions of Norwegian lay people regarding the involuntary 191 admission of schizophrenic patients. Their findings nicely complemen- 192 ted those of Steinert et al. (2005). In the case of a patient in an early 193 phase of schizophrenia, 39\% of the participants supported compulsory 194 admission. In the case of a violent patient with delusions, 80\% of the par- 195 ticipants supported compulsory admission. Wynn et al. (2007) found 196 basically the same results when they examined Norwegian psycholo- 197 gists instead of the general public.

\subsection{The present study}

The present study examined the views about involuntary hospital- 200 ization of lay people and health professionals in France. It differed 201 from the other studies in that, as in several studies recently con- 202 ducted on other aspects of medical ethics (Guedj, Muñoz Sastre, 203 Mullet, \& Sorum, 2009; Teisseyre, Duarte dos Reis, Sorum, \& Mullet, 204 2009; Teisseyre, Mullet, \& Sorum, 2005), it examined the mental pro- 205 cess by which a person arrives at the conclusion that compulsory hos- 206 pitalization is acceptable or not. In addition, the present study aimed 207 at delineating the possibly diverse positions that individuals - both 208 lay people and health professionals - may have regarding involuntary 209 hospitalization. As stated by Steinert et al. (2005, p. 635), 210 
"compulsory procedures are based on traditions and personal attitudes to a considerable degree" (see also Monahan, 1992). In other words, among the same population, different philosophies about coercion may co-exist.

The present study, like many previous studies (e.g., Steinert et al., 2005), used scenarios; that is, participants were instructed to consider concrete cases and indicate each time whether, in their view, involuntary hospitalization was an acceptable solution. The factors incorporated in the scenarios were those more commonly encountered in the literature as associated with decisions to hospitalize involuntarily: (a) patient's lack of insight and inability to adhere to treatment (e.g., Putkonen \& Vollm, 2007; Swanson, Van McCrary, Swartz, Van Dorn, \& Elbogen, 2007), (b) patient's risk of harm to self (e.g., Carter, Safranko, Lewin, Whyte, \& Bryant, 2006; Dammak \& Ayadi, 2009; Elger \& Harding, 2004; Swanson et al., 2007), (c) patient's risk of harm to others (e.g., Dammak \& Ayadi, 2009; Steinert et al., 2005; Wynn et al. 2006), and (d) attitude of the relatives or substitute decision makers (Dawson \& Kämpf, 2006; Elger \& Harding, 2004; Kallert et al., 2007).

We expected that, at the overall level, the less patients adhere to treatment, the more patients pose a risk to self and/or others, and the more the relatives' attitude is favorable to hospitalization, the more acceptable will be compulsory admission; such effects have been separately demonstrated in earlier studies. At the individual level, we expected to find multiple positions, based on different ways of valuing and combining the pieces of information. We hypothesized that a small group of people would consider involuntary hospitalization as unacceptable irrespective of circumstances. Such a minority group has already been found by Wynn et al. (2007), and minority groups of this kind have been found in ethics studies over a range of problems (e.g., Esterle, Munoz Sastre, \& Mullet, 2008; Guedj et al., 2005; Guedj et al., 2009). We hypothesized that another group of participants would take into account only the threat to others, in accordance with the main thrust of French law. Finally, we hypothesized that a third group of persons would take into account all factors, and we expected this group to include most of the health professionals, who would be sensitive to the multiple factors involved in deciding to hospitalize a patient against his or her will.

\section{Method}

\subsection{Participants}

The 154 participants (106 females, 48 males) were unpaid volunteers from the region of Toulouse, France, who were informed about the goals of the study and gave their consent. Their mean age was 36 years $(S D=14.37$, range $=18-77)$. One hundred twenty-three participants were lay people, 20 were nurses working in hospitals, 5 were psychologists, and 6 were physicians. None of the nurses or physicians worked with psychiatric patients.

Among the 123 lay people, $41 \%$ had a university degree, 59\% had completed secondary education but did not have university degree, and $16 \%$ had been directly confronted with this kind of problem in their family.

The lay people were approached by two trained research assistants while they were walking along the main sidewalks of Toulouse. Overall, 200 persons were contacted, and after having received a full explanation of the procedure, $61.5 \%$ of them agreed to participate. The professionals were contacted at the hospital.

\subsection{Material}

The material consisted of 36 cards containing a scenario of a few lines, a question, and a response scale. The scenarios were composed according to a four within-subject factor design, presented in the following order: (a) the patient's level of adherence to treatment (agrees to take his or her medication on a regular basis or completely refuses to take the drugs that have been prescribed), (b) the level of 272 risk of suicide (no real risk, intermediate risk, or multiple prior suicide 273 attempts), (c) the level of risk of serious harm to others (no real risk, 274 intermediate risk, or history of violence against others), and (d) the 275 extent to which the patient's relatives are favorable to coercion and 276 forced treatment (favorable or unfavorable), $2 \times 3 \times 3 \times 2$. Gender 277 and age were constants: all patients were aged $55-60$ years and iden- 278 tified as "Mr."

Under each scenario were a question and a response scale. The 280 question was, "To what extent do you believe that the physician's de- 281 cision to undertake involuntary hospitalization is acceptable in this 282 case"? The response scale was an 11-point scale (0-10) with a left- 283 hand anchor of "Not acceptable at all" and a right-hand anchor of 284 "Completely acceptable." Two examples are given in the Appendix 285 A. The cards were arranged by chance and in a different order for 286 each participant.

\subsection{Procedure}

The site was a vacant classroom in the university. Each person was 289 tested individually by one of the research assistants. As recom- 290 mended by Anderson (1982), the session had two phases. In the fa- 291 miliarization phase, the experimenter explained to each participant 292 what was expected and presented him or her with 18 scenarios 293 taken from the complete set. The participant then provided an accept- 294 ability rating for each story. After completing the 18 ratings, the par- 295 ticipant was allowed to compare responses and change them. In the 296 experimental phase, the whole set of 36 scenarios was presented. 297 Each participant provided ratings at his or her own pace, but was no 298 longer allowed to compare responses nor to go back and make 299 changes as in the familiarization phase. In both phases, the experi- 300 menters routinely made certain that each participant, regardless of 301 age or educational level, was able to grasp all the necessary informa- 302 tion before making a rating.

The participants took 15-30 min to complete both phases. The ex- 304 perimental phase went quickly because they were already familiar 305 with the task and the material. The participants knew in advance 306 how long the experiment would last. None of them complained 307 about the number of vignettes they were required to evaluate. The re- 308 search was approved by the Ethics and Work laboratory of the Insti- 309 tute of Advanced Studies, and informed consent was obtained from 310 all participants in the study.

\section{Results}

A cluster analysis was performed on the raw data. Four clusters 313 were identified. Three of these fours clusters are shown in Fig. 1. No 314 significant difference in the composition of these clusters as a func- 315 tion of age and gender was found. ANOVAs were performed on the 316 data from each cluster. Their design was Adherence to treatmen- 317 $\mathrm{t} \times$ Risk of homicide $\times$ Risk of suicide $\times$ Relatives' attitude, $2 \times 3 \times 3 \times 2$. 318 The results are shown in Table 1.

The first cluster $(N=7)$ was termed Never Acceptable since the 320 responses were always close to the left side of the scale. The mean 321 value of the responses was 1.30. The cluster is not depicted in Fig. 1322 because the responses were very low for every combination of patient 323 characteristics. The cluster was composed of six (of 20) nurses and 324 one physician.

In the other three clusters, responses varied to some degree for 326 different scenarios. The second cluster $(N=35)$ was termed Threat 327 to Others since the only factor that had a strong effect was the risk 328 of homicide (see top panels in Fig. 1). Acceptability was judged 329 much higher when the risk was high $(\mathrm{M}=8.68)$ than when it was 330 low $(\mathrm{M}=2.94)$. The mean value of the responses was 5.82. This clus- 331 ter was composed of 32 (of 123) lay persons, two nurses, and one 332 
M. Guedj et al. / International Journal of Law and Psychiatry xxx (2011) xxx-xxx
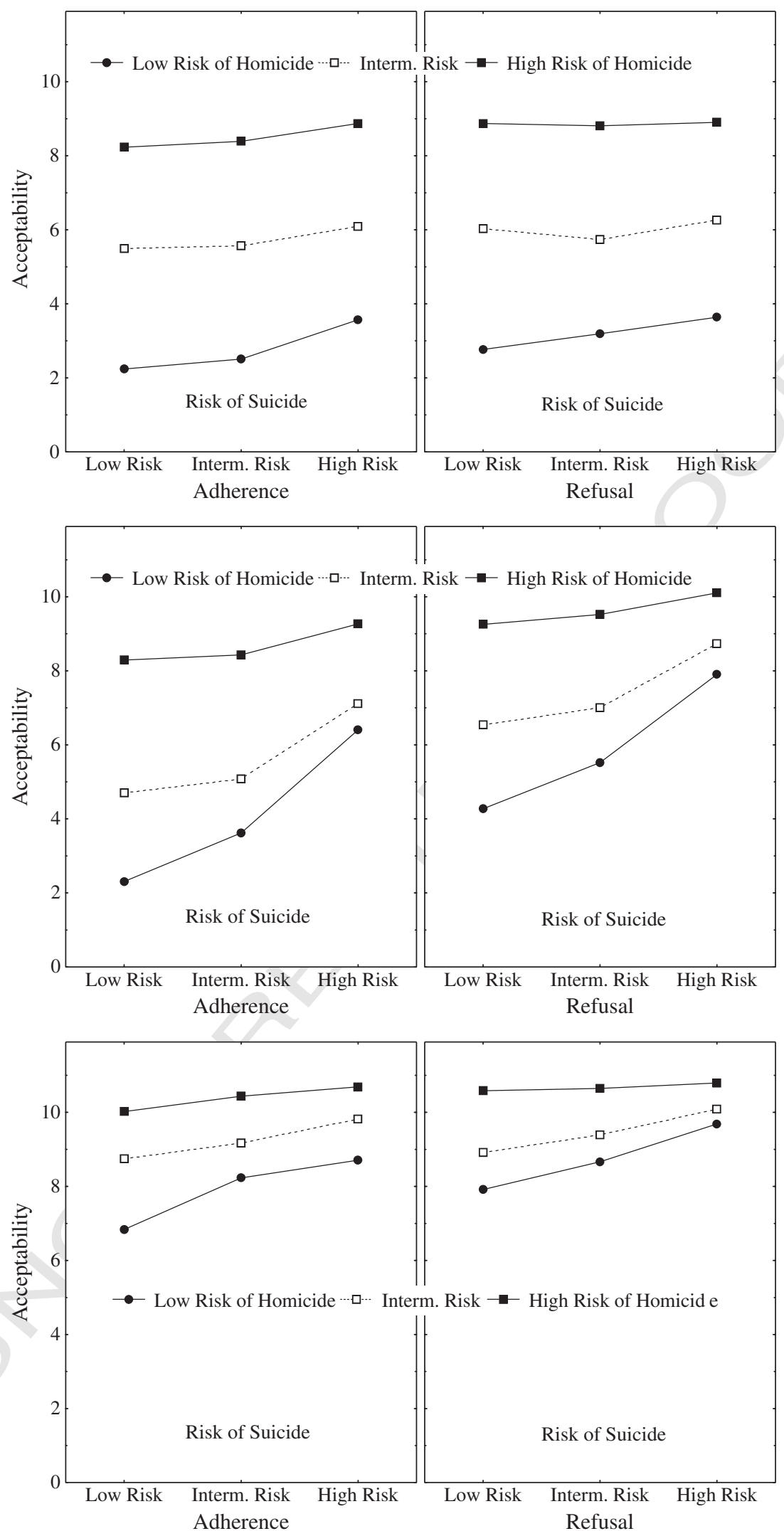

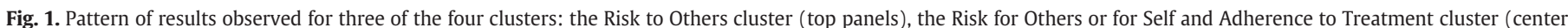

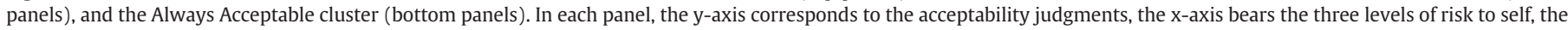
three curves correspond to the three levels of risk to others, and the two panels correspond to the two levels of adherence to treatment. 
t1.1 Table 1

Results of the ANOVAs for each cluster. The higher-order interactions, all non significant, have been omitted.

\begin{tabular}{|c|c|c|c|c|c|c|c|c|}
\hline t1.3 & & Effect & & Error & & & & \\
\hline $\mathrm{t} 1.4$ & Factor & $d f$ & MS & $d f$ & MS & $F$ & $p$ & $\operatorname{Eta}^{2} \mathrm{p}$ \\
\hline $\mathrm{t} 1.5$ & \multicolumn{8}{|l|}{ Never Acceptable } \\
\hline $\mathrm{t} 1.6$ & Relatives & 1 & 32.14 & 6 & 14.62 & 2.20 & $n s$ & .27 \\
\hline $\mathrm{t} 1.7$ & Homicide & 2 & 46.96 & 12 & 6.59 & 7.13 & .01 & .54 \\
\hline $\mathrm{t} 1.8$ & Suicide & 2 & 27.53 & 12 & 5.25 & 5.24 & $n s$ & .47 \\
\hline $\mathrm{t} 1.9$ & Adherence & 1 & 44.59 & 6 & 8.12 & 5.49 & ns & .48 \\
\hline $\mathrm{t} 1.10$ & Relatives $\times$ Homicide & 2 & 1.75 & 12 & 1.69 & 1.03 & $n s$ & .15 \\
\hline $\mathrm{t} 1.11$ & Relatives $\times$ Suicide & 2 & 5.44 & 12 & 3.18 & 1.71 & ns & .22 \\
\hline $\mathrm{t} 1.12$ & Homicide $\times$ Suicide & 4 & 2.95 & 24 & 1.05 & 2.80 & $n s$ & .32 \\
\hline $\mathrm{t} 1.13$ & Relatives $\times$ Adherence & 1 & 0.40 & 6 & 2.33 & 0.17 & $n s$ & .03 \\
\hline $\mathrm{t} 1.14$ & Homicide $\times$ Adherence & 2 & 6.86 & 12 & 2.72 & 2.52 & $n s$ & .30 \\
\hline $\mathrm{t} 1.15$ & Suicide $\times$ Adherence & 2 & 1.10 & 12 & 1.72 & 0.64 & ns & .10 \\
\hline \multicolumn{9}{|l|}{$\mathrm{t} 1.16$} \\
\hline $\mathrm{t} 1.17$ & Risk to Others & & & & & & & \\
\hline $\mathrm{t} 1.18$ & Relatives & 1 & 12.40 & 34 & 3.25 & 3.82 & $n s$ & .10 \\
\hline $\mathrm{t} 1.19$ & Homicide & 2 & 3460.47 & 68 & 24.13 & 143.43 & .00 & .81 \\
\hline $\mathrm{t} 1.20$ & Suicide & 2 & 51.50 & 68 & 3.02 & 17.07 & .00 & .33 \\
\hline $\mathrm{t} 1.21$ & Adherence & 1 & 49.21 & 34 & 4.37 & 11.25 & .00 & .25 \\
\hline $\mathrm{t} 1.22$ & Relatives $\times$ Homicide & 2 & 4.18 & 68 & 2.48 & 1.68 & $n s$ & .05 \\
\hline $\mathrm{t} 1.23$ & Relatives $\times$ Suicide & 2 & 4.50 & 68 & 1.86 & 2.42 & ns & .07 \\
\hline $\mathrm{t} 1.24$ & Homicide $\times$ Suicide & 4 & 9.50 & 136 & 3.06 & 3.10 & ns & .08 \\
\hline $\mathrm{t} 1.25$ & Relatives $\times$ Adherence & 1 & 1.33 & 34 & 3.03 & 0.44 & $n s$ & .01 \\
\hline $\mathrm{t} 1.26$ & Homicide $\times$ Adherence & 2 & 1.44 & 68 & 3.84 & 0.37 & $n s$ & .01 \\
\hline $\mathrm{t} 1.27$ & Suicide $\times$ Adherence & 2 & 8.92 & 68 & 2.40 & 3.72 & $n s$ & .10 \\
\hline \multicolumn{9}{|l|}{$\mathrm{t} 1.28$} \\
\hline $\mathrm{t} 1.29$ & \multicolumn{8}{|c|}{ Risk to Self or to Others and Adherence } \\
\hline $\mathrm{t} 1.30$ & Relatives & 1 & 87.67 & 87 & 5.10 & 17.18 & .01 & .16 \\
\hline $\mathrm{t} 1.31$ & Homicide & 2 & 4632.53 & 174 & 9.53 & 485.87 & .01 & .85 \\
\hline $\mathrm{t} 1.32$ & Suicide & 2 & 1579.00 & 174 & 6.21 & 254.38 & .01 & .75 \\
\hline $\mathrm{t} 1.33$ & Adherence & 1 & 1822.73 & 87 & 9.29 & 196.29 & .01 & .69 \\
\hline $\mathrm{t} 1.34$ & Relatives $\times$ Homicide & 2 & 0.56 & 174 & 2.04 & 0.28 & $n s$ & .01 \\
\hline $\mathrm{t} 1.35$ & Relatives $\times$ Suicide & 2 & 4.71 & 174 & 2.64 & 1.78 & $n s$ & .02 \\
\hline $\mathrm{t} 1.36$ & Homicide $\times$ Suicide & 4 & 199.32 & 348 & 3.35 & 59.52 & .01 & .41 \\
\hline $\mathrm{t} 1.37$ & Relatives $\times$ Adherence & 1 & 1.42 & 87 & 1.72 & 0.82 & $n s$ & .01 \\
\hline $\mathrm{t} 1.38$ & Homicide $\times$ Adherence & 2 & 60.14 & 174 & 3.03 & 19.84 & .01 & .19 \\
\hline $\mathrm{t} 1.39$ & Suicide $\times$ Adherence & 2 & 7.84 & 174 & 2.91 & 2.69 & $n s$ & .03 \\
\hline \multicolumn{9}{|l|}{$\mathrm{t} 1.40$} \\
\hline $\mathrm{t} 1.41$ & Always Acceptable & & & & & & & \\
\hline $\mathrm{t} 1.42$ & Relatives & 1 & 50.07 & 23 & 3.40 & 14.71 & .01 & .39 \\
\hline $\mathrm{t} 1.43$ & Homicide & 2 & 345.14 & 46 & 6.05 & 57.03 & .01 & .71 \\
\hline $\mathrm{t} 1.44$ & Suicide & 2 & 91.18 & 46 & 3.35 & 27.18 & .01 & .54 \\
\hline $\mathrm{t} 1.45$ & Adherence & 1 & 43.56 & 23 & 3.40 & 12.80 & .01 & .36 \\
\hline $\mathrm{t} 1.46$ & Relatives $\times$ Homicide & 2 & 1.87 & 46 & 0.94 & 1.98 & $n s$ & .08 \\
\hline $\mathrm{t} 1.47$ & Relatives $\times$ Suicide & 2 & 1.91 & 46 & 1.13 & 1.69 & ns & .07 \\
\hline $\mathrm{t} 1.48$ & Homicide $\times$ Suicide & 4 & 12.11 & 92 & 2.00 & 6.05 & .01 & .21 \\
\hline $\mathrm{t} 1.49$ & Relatives $\times$ Adherence & 1 & 0.12 & 23 & 1.40 & 0.08 & ns & .01 \\
\hline $\mathrm{t} 1.50$ & Homicide $\times$ Adherence & 2 & 8.06 & 46 & 1.37 & 5.87 & .01 & .20 \\
\hline $\mathrm{t} 1.51$ & Suicide $\times$ Adherence & 2 & 1.76 & 46 & 1.09 & 1.61 & $n s$ & .07 \\
\hline
\end{tabular}

The mean value of the responses was 8.41. The pattern of responses 353 is similar to that in the third cluster except that all responses have a 354 relatively high value. This cluster was composed of 21 lay persons, 355 two nurses, and one physician. Among the 21 lay persons, half of 356 them had a university degree.

\section{Discussion}

Our study of French lay people's and health professionals' judg- 359 ments of the acceptability of involuntary hospitalization of patients 360 with a psychiatric illness had several important findings. First, the 361 vast majority of participants (95\%) agreed that involuntary hospitali- 362 zation is acceptable under certain conditions. Some (16\%), to our sur- 363 prise, found it acceptable in all conditions. Only a small minority (5\%) 364 was, as expected, systematically opposed to it.

Second, this minority of opponents was composed only of health 366 professionals (in particular, 6 nurses and 1 physician). Even if the 367 health professionals who participated in the present study did not ac- 368 tually work with psychiatric patients, most of them would have been 369 exposed, at least at some point in their careers, to mentally as well as 370 physically ill patients and, as a result, would tend to be less frightened 371 than lay people by these patients. In addition, nurses are used to 372 working closely with patients and developing empathy for them. It 373 is also possible that these health professionals were aware of the crit- 374 icisms of and the alternatives to involuntary hospitalization proposed 375 by psychological and sociological researchers (as discussed in the 376 Introduction). Nonetheless, the majority of health professionals in 377 our study ( $70 \%$ of the nurses, $83 \%$ of the physicians, and $100 \%$ of the 378 psychologists) were not systematically opposed to involuntary hospi- 379 talization. In comparison, Steinert et al. (2005) found, in their study of 380 four European countries, that psychologists and social workers, but 381 not nurses, psychiatrics, or other doctors, were less in favor of invol- 382 untary hospitalization than lay people.

Third, as expected, by far the most important factor in judging the 384 acceptability of involuntary hospitalization was the risk to other peo- 385 ple (in particular, the danger of committing a homicide). This was in 386 accordance with French law that allows the civil authorities, with ad- 387 vice of and, in practice, at the request of, the patient's psychiatrist, to 388 hospitalize such a patient against his or her will. In contrast, the atti- 389 tude of relatives was taken into account either very little (by the ma- 390 jority cluster) or not at all. Even though French law allows the family 391 to instigate involuntary hospitalization, in actual practice, as reflected 392 in the participants' responses, request by the family was not consid- 393 ered as a relevant criterion after controlling for the influence of the 394 factors of risk to self and risk to others.

Fourth, as also expected, the majority of both lay people (57\%) and 396 health professionals (58\%) took into account multiple factors. They 397 were sensitive to the patient's risk to himself or herself (the danger 398 of suicide) as well as to others (the danger of homicide), and they 399 combined these two factors in a complex way, so that a high level 400 of only one of the two risks was sufficient to make involuntary hospi- 401 talization acceptable. Even though French law speaks in general terms 402 of hospitalization at the request of a third party if "his condition re- 403 quires immediate care in addition to constant surveillance in a hospi- 404 tal setting," lay people as well as health professionals realize that 405 threat of suicide is such a condition. This finding was consistent with 406 the findings by Pescosolido et al. (1999) that coercion was readily 407 endorsed by American lay people for patients suffering from schizo- 408 phrenia in case of either threat to self or threat to others (more than 409 $90 \%$ favorable to coercion in each case).

Our study has limitations. First, our samples, especially of health 411 professionals, were of modest size; were, in the case of the health 412 professionals, quite heterogeneous; were convenience samples; and 413 were composed only of people living in the south of France. General- 414 izations of our findings to other groups must be made with caution, 415 and further studies of health professionals, particularly of nurses, 416 
need to be done. Second, we presented the participants with scenarios, not with real patients. While scenarios are less realistic than patients, their use is more feasible, allows more precise statistical analyses of the variables, and has been repeatedly defended (Froberg \& Kane, 1989; Ulrich \& Ratcliffe, 2008). Third, all the scenarios were about a patient suffering from severe psychiatric illness. As in Pescosolido et al. (1999), other conditions - alcohol dependence, drug dependence, and depression - could have been considered, and future studies should assess to what extent our results can be generalized to these conditions.

In spite of these limitations, our study is useful in showing that most French lay people and health professionals, at least in our study, are in agreement with the implications of French law and of the European Convention on Human Rights that beneficence and public safety must supersede patient autonomy when mentally-ill persons pose a grave risk to themselves and, more importantly, to others. Future studies should be conducted to assess the extent to which people think that accurate prediction of future violence among people suffering from mental illness is feasible and that alternative, "contractual" solutions (Monahan et al., 2003) can be put in place. In addition, it will be important to watch the impact of the UN Convention on the Rights of Persons with Disabilities on judicial rulings, legislation, and public opinion in countries, like France, that ratify it (as well as in countries, like the United States, that may not) (Lee, 2011).

\section{Uncited references}

Guedj et al., 2006

Kallert, 2008

Wynn, 2004

\section{Appendix A}

Two examples of scenarios (in English translation and French original)

$\# 1$

Mr. Duhamel is 55 years old. He suffers from very serious psychiatric problems. His capacity of judgment is greatly altered. Mr. Duhamel is willing nonetheless to take, in a regular manner, the treatments prescribed for him.

For the past several days, Mr. Duhamel has not gone to work and is living in seclusion in his apartment. His psychiatrist, Dr. Fournier, considers that his risk of suicide is low. Mr. Duhamel has never, up until now, tried to end his life.

The risk that Mr. Duhamel will commit a homicide seems equally low. He has never, it appears, acted in a violent and potentially dangerous way towards another person.

The family of Mr. Duhamel, very worried, would favor involuntary hospitalization in a psychiatric hospital.

In light of the evolution of the situation, Dr. Fournier decides to set in motion the procedure for involuntary hospitalization.

To what extent do you think that such a decision is acceptable?

Not at all acceptable $0--0-0-0-0-0-0-0-0-0-0$ Completely acceptable

Monsieur Duhamel a 55 ans. Il souffre de troubles psychiatriques très graves. Ses capacités de jugement sont très altérées. Monsieur Duhamel accepte néanmoins de prendre, de manière régulière, les traitements qui lui ont été prescrits.

Depuis plusieurs jours, Monsieur Duhamel ne s'est plus rendu à son travail, et vit reclus dans son appartement. Son médecin psychiatre, le Docteur Fournier, estime que le risque de suicide est, chez ce patient, faible. Monsieur Duhamel n'a jamais, jusqu'ici, tenté de mettre fin à ses jours.
Le risque que Monsieur Duhamel commette un homicide apparaît 477 également faible. Celui-ci n'a, semble-t-il, jamais présenté de compor- 478 tements violents et potentiellement dangereux pour autrui. $\quad 479$

La famille de Monsieur Duhamel, très inquiète, serait favorable à 480 une hospitalisation d'office en hôpital psychiatrique. 481

Compte tenu de l'évolution de la situation, le docteur Fournier 482 décide de lancer la procédure d'hospitalisation d'office. 483

Dans quelle mesure pensez-vous qu'une telle décision est accept- 484 able?

Pas du Tout acceptable $0--0--0--0--0--0--0--0--0--486$ $0--0$ Tout à fait acceptable

\#2 even refuses to take the treatments prescribed for him.

491

For the past several days, Mr. Bernard has not gone to work and is 492 living in seclusion in his apartment. His psychiatrist, Dr. Gramont, 493 considers that his risk of suicide is high. Mr. Bernard has tried, on several 494 occasions, to end his life.

The risk that Mr. Bernard will commit a homicide seems equally 496 high. Indeed, he is well-known for having already tried to take the 497 lives of other persons.

The family of Mr. Bernard is worried but does not favor involun- 499 tary hospitalization in a psychiatric hospital.

In light of the evolution of the situation, Dr. Bernard decides to set 501 in motion the procedure for involuntary hospitalization.

To what extent do you think that such a decision is acceptable? 503

Not at all acceptable $0--0-0-0-0-0-0-0-0-0-0$ Completely 504 acceptable

Monsieur Bernard a 57 ans. Il souffre de troubles psychiatriques 506 très graves. Ses capacités de jugement sont très altérées. Monsieur 507 Bernard refuse même de prendre les traitements qui lui ont été 508 prescrits.

Depuis plusieurs jours, Monsieur Bernard ne s'est plus rendu à son 510 travail, et vit reclus dans son appartement. Son médecin psychiatre, le 511 Docteur Gramont, estime que le risque de suicide est, chez ce patient, 512 élevé. Monsieur Bernard a tenté, à plusieurs reprises, de mettre fin à 513 ses jours.

Le risque que Monsieur Bernard commette un homicide apparaît 515 également élevé. En effet, celui-ci est connu pour avoir attenté déjà 516 à la vie d'autres personnes.

La famille de Monsieur Bernard est inquiète mais ne se montre pas 518 favorable à une hospitalisation d'office en hôpital psychiatrique. $\quad 519$

Compte tenu de l'évolution de la situation, le docteur Gramont 520 décide de lancer la procédure d'hospitalisation d'office. 521

Dans quelle mesure pensez-vous qu'une telle décision est ac- 522 ceptable?

Pas du Tout acceptable $0--0--0--0--0--0--0--0--0--524$ $0--0$ Tout à fait acceptable

\section{References}

Alexius, B., Berg, K., \& Aberg-Wistedt, A. (2002). Psychiatrists' perception of psychiatric 527 commitment. International Journal of Law and psychiatry, 25, 109-117. Anderson, N. H. (1982). Methods of information integration theory. New York: Academic 529 Press.

Bonnie, R. J., \& Monahan, J. (in press). From coercion to contract: Reframing the debate 531 on mandated community treatment for people with mental disorders. Law and 532 Human Behavior.

Carter, G. L., Safranko, I., Lewin, T. J., Whyte, I. M., \& Bryant, J. L. (2006). Psychiatric hos- 534 pitalization and deliberate self-poisoning. Suicide and Life-Threatening Behavior, 36, 535 213-222.

Cour d'appel d'Aix-en-Provence (2008). Audience publique du jeudi 2 octobre 2008. Avail- 537 able at http://www.legifrance.gouv.fr/affichJuriJudi.do?oldAction=rechExpJuriJudi\&id 538 Texte $=$ JURITEXT000019790881\&fastReqId $=1957480516 \&$ fastPos $=3$. Accessed on 29539 December 2010.

Cour d'appel de Bordeaux (2006). Audience publique du lundi 23 janvier 2006. Avail- 541 able at http://www.legifrance.gouv.fr/affichJuriJudi.do?oldAction=rechExpJuri 542 Judi\&idTexte $=$ JURITEXT000006947091\&fastReqId $=1957480516 \&$ fastPos $=9 . \quad 543$ Accessed on 29 December 2010. 
Dammak, M., \& Ayadi, N. (2009). Variables related to admission decisions. Annales Medico-Psychologiques, 167, 195-199.

Dawson, J., \& Kämpf, A. (2006). Incapacity principles in mental health laws in Europe Psychology, Public Policy and Law, 12, 310-331.

Elger, B. S., \& Harding, T. W. (2004). Should a suicidal patient with Huntington disease be hospitalized against her will? Attitudes among future physicians and lawyers and discussion of ethical issues. General Hospital Psychiatry, 26, 136-144.

European Court of Human Rights (2010). Convention for the protection of human rights and fundamental freedoms. As amended by protocols nos, 11 and 14 . Available at http://www.echr.coe.int/NR/rdonlyres/D5CC24A7-DC13-4318-B4575C9014916D7A/0/ENG_CONV.pdf. Accessed on 30 October 2011.

European Court of Human Rights (2011). Factsheet - Mental health. Available at http:// www.echr.coe.int/NR/rdonlyres/4F36D680-0FA4-4124-98CE-A20FB9E754FC/0/FICHES Santé_mentale_EN.pdf. Accessed on 30 October 2011.

Froberg, D. G., \& Kane, R. L. (1989). Methodology for measuring health-state preferencesIV: Progress and a research agenda. Journal of Clinical Epidemiology, 42, 675-685.

Guedj, M., Gibert, M., Maudet, A., Muñoz Sastre, M. T., Mullet, E., \& Sorum, P. C. (2005) Acceptability of ending a patient's life. Journal of Medical Ethics, 31, 311-317.

Guedj, M., Muñoz Sastre, M. T., Mullet, E., \& Sorum, P. C. (2006). Under what conditions is the breaking of confidentiality acceptable to lay people and health professionals? Journal of Medical Ethics, 32, 414-419.

Guedj, M., Muñoz Sastre, M. T., Mullet, E., \& Sorum, P. C. (2009). Is it acceptable for psychiatrist to break confidentiality to protect a wife from violence? International Journal of Law and Psychiatry, 32, 108-114.

Habermeyer, E., Rachvoll, U., Felthous, A. R., Bukhanowsky, A. O., \& Gleyzer, R. (2007). Hospitalization and civil commitment of individuals with psychopathic disorders in Germany, Russia, and the United States. In A. Felthous, \& S. Henning (Eds.), International handbook on psychopathic disorders and the law, Vol. 2. (pp. 35-60)New York: Wiley.

Kallert, T. W. (2008). Coercion in psychiatry. Current Opinion in Psychiatry, 21, 485-489. Kallert, T. W., Glöckner, M., \& Schützwohl, M. (2008). Involuntary vs. voluntary hospital admission. European Archives of Psychiatry and Clinical Neuroscience, 258, 195-209.

Kallert, T. W., Rymaszewska, J., \& Torres-Gonzalez, F. (2007). Differences in legal regulations concerning involuntary psychiatric hospitalization in twelve European countries: Implications for clinical practice. The International Journal of Forensic Mental Health, 6, 197-207.

Lee, B. L. (2011). The U.N. convention on the rights of persons with disabilities and its impact upon involuntary civil commitment of individuals with developmental disabilities. Available at. Columbia Journal of Law and Social Problems, 44. (pp. 393-445) http://www.columbia.edu/cu/jlsp/pdf/Spring\%202011/Lee.JLSP.44.3.D.pdf Accessed on 8 November 2011

Loi $n^{\circ}$ 2011-803 du 5 juillet (2011). Available at http://www.legifrance.gouv.fr/ affichTexte.do?cidTexte $=$ JORFTEXT000024312722\&dateTexte\&categorieLien $=\mathrm{id}$ Accessed on 31 October 2011.

Loi no 90-527 du 27 juin (1990). Available at http://www.ch-charcot56.fr/textes/ 90-527.htm. Accessed on 25 March 2010.

Luchins, D. J., Cooper, A. E., Hanrahan, P., \& Rasinski, K. (2006). Psychiatrists' attitudes toward involuntary treatment. Psychiatric Services, 55, 1058-1060.

Luchins, D. J., Hanrahan, P., \& Heyrman, M. J. (2006). Lawyers' attitudes toward involuntary treatment. Journal of the American Academy of Psychiatry and the Law, 34, 492-500. Monahan, J. (1992). Mental disorder and violent behavior. American Psychologist, 47, 511-521.
Monahan, J. (2006). Tarasoff at thirty: How developments in science and policy shape 597 the common law. University of Cincinnati Law Review, 75, 497-521.

Monahan, J., Steadman, H. J., Appelbaum, P. S., Grisso, T., Mulvey, E. P., Roth, L. H., et al. 599 (2006). The classification of violence risk. Behavioral Science and the Law, 24, 600 721-730.

Monahan, J., Swartz, M., \& Bonnie, R. J. (2003). Mandated treatment in the community 602 for people with mental disorders. Mental Health Law, 22, 28-38. 603

Pescosolido, B. A., Monahan, J., Link, B., Stueve, A., \& Kikuzawa, S. (1999). The public's 604 view of the competence, dangerousness, and need for legal coercion of persons 605 with mental health problems. American Journal of Public Health, 89, 1339-1345. 606 Putkonen, H., \& Vollm, B. (2007). Compulsory psychiatric detention and treatment in 607 Finland. Psychiatric Bulletin, 31, 101-103.

Skeem, J. L., Miller, J. D., Mulvey, E., Tieman, J., \& Monahan, J. (2005). Using a five-factor 609 lens to explore the relation between personality traits and violence in psychiatric 610 patients. Journal of Consulting and Clinical Psychology, 73, 454-465.

Steinert, T., \& Lepping, P. (2009). Legal provisions and practice in the management of 612 violent patients. A case vignette study in 16 European countries. European Psychiatry, 613 24, 135-141.

Steinert, T., Lepping, P., Baranyai, R., Hoffmann, M., \& Leherr, H. (2005). Compulsory 615 admission and treatment in schizophrenia. Social Psychiatry and Psychiatric Epi- 616 demiology, 40, 635-641.

Swanson, J. W. Van McCrary, S., Swartz, M. S., Van Dorn, R. A. \& Elbogen, E. B. (2007). 618 Overriding psychiatric advance directives: Factors associated with psychiatrists' 619 decisions to preempt patients' advance refusal of hospitalization and medication. 620 Law and Human Behavior, 31, 77-90.

Szmukler, G., \& Holloway, F. (1998). Mental health legislation is now a harmful anach- 622 ronism. Psychiatric Bulletin, 22, 662-665. 623

Taylor, P. J., \& Monahan, J. (1996). Dangerous patients or dangerous diseases? British 624 Medical Journal, 312, 967-969. 625

Teisseyre, N., Duarte dos Reis, I., Sorum, P. C., \& Mullet, E. (2009). The acceptability 626 among French lay persons of ending the lives of damaged newborns. Journal of 627 Medical Ethics, 35, 701-708.

Teisseyre, N., Mullet, E., \& Sorum, P. C. (2005). Under what conditions is euthanasia 629 acceptable to lay people and health professionals? Social Science and Medicine, 630 60, 357-368.

Ulrich, C. M. \& Ratcliffe, S. J. (2008). Hypothetical vignettes in empirical bioethics 632 research. In L. Jacoby, \& L. A. Siminoff (Eds.), Empirical methods for bioethics: A 633 primer (pp. 161-181). San Diego: Elsevier.

United Nations (2006). Convention on the rights of persons with disabilities. Available 635 at http://www.un.org/disabilities/convention/conventionfull.shtml. Accessed on 636 8 November 2011.

Wynn, R. (2004). Psychiatric inpatients' experiences with restraint. The Journal of Forensic 638 Psychiatry and Psychology, 15, 124-1244. 639

Wynn, R., Myklebust, L. -H., \& Bratlid, T. (2006). Attitudes to coercion among health- 640 care workers and the general public in Norway. Journal of Psychiatric Intensive 641 Care, 2, 31-37.

Wynn, R., Myklebust, L. -H., \& Bratlid, T. (2007). Psychologists and coercion: Decisions 643 regarding involuntary psychiatric admission and treatment in a group of Norwegian 644 psychologists. Nordic Journal of Psychiatry, 61, 433-437. 